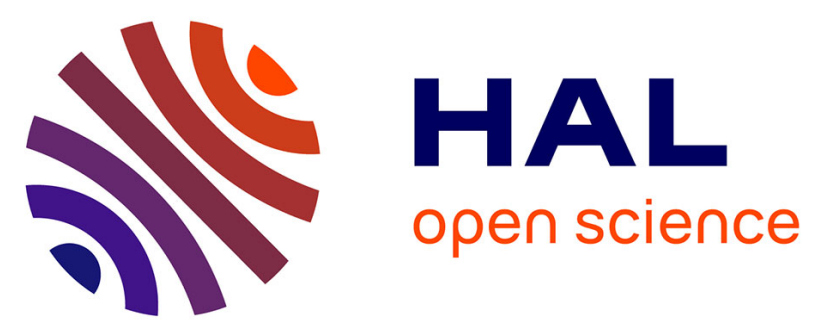

\title{
The Strategies and Effectiveness of Conservation NGOs in the Global Voluntary Standards: The Case of the Roundtable on Sustainable Palm-Oil
}

\author{
Denis Ruysschaert, Denis Salles
}

\section{- To cite this version:}

Denis Ruysschaert, Denis Salles. The Strategies and Effectiveness of Conservation NGOs in the Global Voluntary Standards: The Case of the Roundtable on Sustainable Palm-Oil. Conservation and Society, 2016, 14 (2), pp.73-85. 10.4103/0972-4923.186332 . hal-01379923

HAL Id: hal-01379923

https://hal.science/hal-01379923

Submitted on 12 Oct 2016

HAL is a multi-disciplinary open access archive for the deposit and dissemination of scientific research documents, whether they are published or not. The documents may come from teaching and research institutions in France or abroad, or from public or private research centers.
L'archive ouverte pluridisciplinaire HAL, est destinée au dépôt et à la diffusion de documents scientifiques de niveau recherche, publiés ou non, émanant des établissements d'enseignement et de recherche français ou étrangers, des laboratoires publics ou privés. 


\title{
The Strategies and Effectiveness of Conservation NGOs in the Global Voluntary Standards: The Case of the Roundtable on Sustainable Palm-Oil
}

\author{
Denis Ruysschaert ${ }^{\mathrm{a}, \#}$ and Denis Salles ${ }^{\mathrm{b}}$ \\ ${ }^{a}$ Centre d'Étude et de Recherche Travail, Pouvoir (CERTOP), Université Toulouse, France
}

'Institut National de Recherche en Sciences et Technologies Pour l'Environnement et l'Agriculture (IRSTEA), Bordeaux, France

\#Corresponding author. E-mail: Denis.ruysschaert@gmail.com

\begin{abstract}
Conservation non-governmental organisations (NGOs) and firms have been promoting global voluntary standards, such as the Roundtable on Sustainable Palm Oil (RSPO), to produce environmentally responsible goods in tropical countries. This research seeks to understand the strategies and the effectiveness of conservation NGOs with respect to the RSPO. Our research documents that the conservation NGOs, when engaging with the RSPO, may be divided into four categories based on the type of resources mobilised and the conservation goals: 1) 'Collaborative NGOs' seek to change the system from within by providing scientific research-based information, by holding strategic positions and by creating rules; 2) 'Opponent' remains outside the RSPO while using it as a platform for public campaigns; 3) 'Opportunistic' focuses on conserving geographical areas by adopting either collaborative or opponent strategies to reach their goals; and 4) 'Sceptic' supports communities to secure local land rights. These NGOs have implemented strategies that strengthened RSPO's institution. However, the institutionalisation of the RSPO prevents the NGOs from reaching their goals for three reasons: 1) individual NGOs cannot change strategy; 2) NGOs using different engagement strategies are unable to collaborate; and 3) the sceptic NGOs are structurally excluded from the RSPO, though local land rights are a fundamental matter of concern for biodiversity conservation. NGOs would be more effective in reaching their goals either by focussing on their initial conservation objectives or by strategically collaborating with each other outside the structures of the RSPO.
\end{abstract}

Keywords: conservation NGOs, deforestation, green washing, impact, Indonesia, orangutan, palm oil, RSPO, strategies, voluntary agreement

\section{INTRODUCTION}

Tropical forest biodiversity is declining at an alarming rate of more than $1 \%$ per year, largely because of agricultural expansion into forests (WWF et al. 2014). southeast Asian countries, especially Indonesia and Malaysia, follow this trend due to the recent surge of the palm oil industry that

\begin{tabular}{|l|l|}
\hline \multicolumn{2}{|c|}{ Access this article online } \\
\hline Quick Response Code: & Website: \\
\hline & www.conservationandsociety.org \\
\cline { 2 - 3 } & \\
\hline
\end{tabular}

are subsidised by their respective governments (Pye and Bhattacharya 2013; USDA 2014). Once a marginal crop in the eighties, large-scale oil palm plantations are transforming the low land forest landscape in both the countries. In Indonesia alone, plantations cover 110 thousand sq. km, including $60 \%$ for large-scale plantations of several thousand hectares each (DGEC 2014). Additional 150 to 270 thousand sq. km are under permits for further oil palm plantations (Colchester and Chao 2011). Peat land forest areas in both countries are particularly threatened. In 2010, plantations covered over 31,000 sq. km of peat land, with projections between 60,000 and 90,000 sq. $\mathrm{km}$ by 2020 (Miettinen et al. 2012).

Large-scale oil palm plantations greatly impact wild species. The plantations host $65 \%$ less biodiversity than natural forests. They also contribute to forest fragmentation and create an ecological barrier for species (Fitzhebert et al. 2008). Mammals

Copyright: (C) Ruysschaert and Salles 2016. This is an open access article distributed under the terms of the Creative Commons Attribution License, which permits unrestricted use and distribution of the article, provided the original work is cited. Published by Wolters Kluwer - Medknow, Mumbai $\mid$ Managed by the Ashoka Trust for Research in Ecology and the Environment (ATREE), Bangalore. For reprints contact: reprints@medknow.com 


\section{4 / Ruysschaert and Salles}

are particularly vulnerable because they require large territories of several square kilometres for a viable population. Mainly due to recent oil palm expansion, orangutan, tiger, elephant and rhinoceros in southeast Asia have been classified as "endangered" or "critically endangered" on the IUCN Red List (IUCN 2015). For instance, the critically endangered Sumatran Orangutan Pongo abelli, with a current population of 6,600 and habitat of around 8,000 sq. km, has lost an estimated $90 \%$ of its original habitat during the twentieth century. Yet this species is still losing about 50 sq. km of its forest habitat each year mainly due to oil palm plantations (Wich et al. 2011; Ruysschaert and Salles 2014). The rise of palm oil production has also resulted in 3,500 land conflicts in palm plantations with local communities in Indonesia between 1997 and 2009 (Jiwan 2013).

It is in this context that the World Wide Fund for Nature (WWF) promoted the establishment of the multi stakeholder private association, Roundtable on Sustainable Palm Oil (RSPO), whose aim is to produce socially and environmental responsible palm oil. In 2001, WWF approached Western firms with a history of operating in southeast Asia, primarily those based in the United Kingdom and the Netherlands (RSPO 2002). Banks and agro-business firms in these countries were seeking to secure their long-term supply and to protect themselves from possible negative environmental campaigns (RSPO 2002). Indeed, their major financial institutions (e.g., Rabobank, Standard Chartered) were financing the firms converting forest into large-scale oil palm plantations. Their main agro-business firms were also buying large quantities of palm oil from southeast Asia (RSPO 2002). This included processors (AAK), consumer good manufacturers (Unilever) and retailers (Mark and Spencer, Sainsbury's). As a prominent example, Unilever is the biggest single user of palm oil in the word.

In 2004, the RSPO was established as an association comprising all private stakeholders within the palm oil supply chain (RSPO 2004). It was divided into seven membership categories: 1) palm oil growers; 2) palm oil processors; 3 ) consumer goods manufacturers; 4) environmental non-governmental organisations (NGOs); 5) social NGOs; 6) banks/investors; and 7) retailers. In 2007, the members agreed on the standard of production, including social and environmental principles and criteria (RSPO 2007).

As the first global standard in agriculture in the tropics, it has been replicated for other commodities such as aquaculture, agro-fuels, cotton, sugar cane, and soy ${ }^{1}$. As of June 2015, the RSPO comprises more than 1,200 ordinary members (RSPO $2015 \mathrm{a}$ ) and certifies $20 \%$ of the globally produced palm oil as sustainable (RSPO 2015b).

Despite the rising number of RSPO members and volumes produced according the standard, lowland natural forest loss is still increasing in Indonesia, with 84,000 sq. km in 2012. Between 2001-2012, Indonesia lost an average 56,000 sq. km of forest per year. Forty per cent of this loss is due to large-scale oil palm plantations on peatland (Margono et al. 2014). Overall the RSPO has not been effective in curbing deforestation due to oil palm plantation (McCarthy 2012; Ruysschaert and Salles 2014).

At the same time, the number of conservation NGO members joining the RSPO has continuously risen, with a total of 30 conservation NGO members by the end of June 2015 (RSPO 2015a). Therefore, this study seeks to understand this growing contradiction between an apparently ineffective RSPO and the continuous, and even increasing interest of conservation NGOs in this scheme. By understanding the roles and effectiveness of conservation NGOs with respect to the RSPO standard, the research seeks to make sense of this inconsistency.

This article takes the position of considering the diversity of conservation NGOs engaged with the RSPO. It formulates the hypothesis that NGOs are strategic players with clear conservation goals mobilising their scarce resources to achieve these goals (Friedberg 1991). Based on what these resources and goals are, NGOs adopt a number of different roles. NGOs can mobilise four broad types of resources to influence the terms of the relationships to their advantage: 1) expertise; 2) relationships outside the system (eg., media, government); 3) communication and information; and 4) institutional rules within the system (Crozier and Friedberg 1977).

RSPO's construction could limit the NGOs ability to have an impact in three complementary ways. The initial reason would be that the institutionalisation forces each individual NGO to adopt a specific strategy as their resources are decreasing while RSPO is structuring. Then, the institutionalisation may impede collaboration between NGOs using different strategies, whereas this collaboration would, in fact, be a key to get leverage. Lastly, some NGOs may be structurally excluded because of their incompatibility with the prevalent capitalistic discourse within the RSPO, although their participation is fundamental, both in term of long-term conservation gains and social justice (Fouilleux 2013; Pye 2013; Cheyns 2014).

\section{IMPORTANCE OF THE NGO EFFECTIVNESS QUESTION TO RESEARCH}

So far researchers have demonstrated that the emergence of certifications for global commodities, such as RSPO, can be qualified as a new capitalist instrument (Fouilleux and Goulet 2012), promoted by dominant economic players (Fouilleux 2013; Oosterveer 2014) and major NGOs (Cheyns 2012; Escobar and Cheyns 2012; Pye 2013), and operating at the expense of local people (Ponte et al. 2011; Fouilleux 2013; Cheyns 2014).

These researches meet the growing political ecologist's consensus on synergistic relationships between the protection of nature and neoliberalism, where, the largest conservation NGOs in terms of staff and turn over (such as WWF or Conservation International) would directly support market expansion (Igoe and Brockington 2007; Benjaminsen and Svarstad 2010; Igoe et al. 2010a,b; Büscher et al. 2014). The main reason would be that the conservation NGOs and capitalist agendas are driven by the convergence of networks of interests (Igoe and Brockington 2007; Barker 
2009; Brockington and Duffy 2010; Igoe et al. 2010b). This limits the NGOs' effectiveness, as they tend to overlook local communities (Chaplin 2004; Igoe and Brockington 2007; Tumusiime and Svarstad 2011), while maintaining that cultural diversity is inseparable from biodiversity conservation (Igoe 2005; Peluso 2012).

Why the NGOs are behaving in such a negative manner from a conservation perspective remains a subject for discussion. One reason seems to be the need for fresh financial resources, as these large NGOs are ever expanding in term of budget and human resources (Chaplin 2004; Barker 2009; Sachedina et al. 2010). As such, these NGOs would tend to behave as a collection of projects without any clear overarching purpose due to a lack of accountability mechanisms (Sachedina et al. 2010) or, worse, being enslaved to their donors' priorities (Chaplin 2004; Barker 2009) and their neoliberal agenda (Brockington and Duffy 2010).

If these findings may be relevant for the biggest NGOs, it tends to overlook the whole range of conservation NGOs (Brockington 2011), even though NGOs' conservation performance in reaching their conservation goals can vary considerably depending on the NGO and the region in which it operates (Igoe et al. 2010b). As a main consequence, studies tend to fall short of solutions aside from the rather populist recommendations to devolve conservation and its finance to the locals (McCarthy 2002; Barker 2009) and join the fight against neoliberalism (Barker 2009; Sachedina et al. 2010). Yet, what can NGOs do to better achieve conservation outcomes?

\section{METHODOLOGY}

To analyse the roles and effectiveness of conservation NGOs in the RSPO, this research takes a political ecology approach. In other words, it is the conjunction of a pattern of interactions made of economic interests (expansion of oil palm plantations for agribusiness), ecological changes (destruction of orangutan rainforest habitat), and political battles (designation of land use and dispossession of local communities from their territories) (Gautier and Benjaminsen 2012). As such, the study is firmly rooted in an acute conflict on land use allocation between conservation NGOs and oil palm growers because of orangutan habitat conversion into plantations, in the lowland forests of Malaysia and Indonesia. This conflict between conservationists and growers takes place against the background of the broader issue of dispossession of forested land from local communities in those countries (Peluso 2012). This approach has the advantage of limiting the scope of the study and maintaining a common thread from the global context of the RSPO to the local tangible ecological reality and social conflict in southeast Asia.

This study involves access to a wide range of materials. The research benefits from in situ observation of the NGOs engaging with the RSPO. Indeed, from October 2006 to October 2011, one of the authors was a staff member of one of the conservation NGOs that is a RSPO member. This provided direct access to information on the specific objectives and the resources of NGOs engaged during the RSPO annual meetings, General Assembly (GA), and RSPO bodies linked to biodiversity conservation, such as the Biodiversity and High Conservation Values Working Group (BHCV WG). This provided first hand information to elaborate the 'playing field', which is how the RSPO functions, and categories (or roles or engagement regimes or strategies) of NGOs based on the resources they mobilise and their conservation goals.

The effectiveness and structural constraints of each of these engagement regimes were investigated by conducting 49 semi-structured interviews from November 2011 to July 2013, which represented 33 institutions, including 11 NGOs (Birdlife, Conservation International, PanEco, Greenpeace Indonesia, Greenpeace International, Leuser International Foundation, Sumatran Orangutan Society, World Conservation Society, WWF, Yayasan Ekosistem Lestari, and Yayasan Pulau Banyak), dealing with palm oil. In addition, Internetbased research was undertaken to obtain publicly available information (reports, press releases, and web pages) between 2001 and June 2015 on the RSPO and on all the main conservation NGOs engaged with the RSPO. This research was complemented by field observations during the European RSPO meeting in London in June 2014 and the RSPO annual meeting in November 2014.

\section{ARGUMENT}

The argument is developed in three parts. First, it describes the 'playing field', how the RSPO formally functions as an institution. Second, it details the four strategies (or roles) of NGOs based on the resources they mobilise and their conservation goals: 1) the collaborative; 2) the opposing; 3) the opportunistic; and 4) the sceptics. Third, it explains the relationship of each of these NGO strategies with the RSPO institutionalising and how it limits their impact.

\section{How RSPO is formally functioning}

RSPO's objective is to promote the growth and use of sustainable palm oil (RSPO 2004). Sustainability is defined as the application of a 50-page guidance document called Principles and Criteria for the Production of Sustainable Palm Oil, which detail eight principles ${ }^{2}$ along with the associated criteria and indicators. The criteria and indicators associated with principles 5.2 and 7.3 specifically engage with biodiversity conservation. Criterion 5.2 requires growers to conserve rare species, habitats, and control hunting (RSPO 2013: 27). Criterion 7.3 requires that new plantings starting from November 2005 do not replace primary forest or High Conservation Value (HCV) areas. These $\mathrm{HCV}$ areas are designated as such due to their importance for biodiversity conservation or for local community's well-being (RSPO 2013: 50).

The choice of criteria and its related indicators resulted from extensive negotiations among members respecting three cardinal rules: 1) inclusive participation from each member 


\section{6 / Ruysschaert and Salles}

category; 2) consensus building in reaching agreements; and 3) transparency during the negotiation process and the decisionmaking. In addition to these rules, debates among members were structured by a scientific research-based managerial discourse as a way to depoliticise the debate among members (Cheyns 2012).

Approved at the RSPO GA of 2007 (RSPO 2007) the guidance document was later revised in 2013 (RSPO 2013) to strengthen its environmental criteria and indicators. Sustainability, therefore, has been an evolving concept, in which each member category defends its own interests. Following the approval of the guidance document, RSPO introduced the Certified Sustainable Palm Oil (CSPO) to the market in 2008. This enabled downstream firms to label the final product with a distinctive CSPO trademark.

The RSPO is a scheme formed with three distinct governing bodies: the GA, the Board of Governors (BG), and the Secretariat. In between the GAs, the BG provides strategic and operational direction. The BG is comprised of 16 members, four for growers and two memberships each for other seven membership categories. The BG members are elected from their specific categories during the GA for a term of two-years. There is great stability in those BG roles. Since the beginning, the manufacturer of consumer goods, Unilever is the President, the processor AAK-UK is the Treasurer, and the environmental NGO WWF is the Vice-president.

The GA is an annual meeting where members can propose new resolutions. Resolutions often seek to interpret the implementation of the guidance document to favour a specific interest, which, for the environmental NGOs is conservation. The GA decision-making process is undertaken by casting votes and endorsement by a simple majority. As a result, to pass any resolution, a member must garner support from downstream firms (palm oil processors, consumer goods manufacturers and retailers) as they represent about $80 \%$ of the RSPO membership (RSPO 2015a). To implement these decisions, the BG establishes working groups or task forces. These working groups are made of members, and function according to the RSPO core principles. They provide recommendations to the $\mathrm{BG}$ on how to implement the GA decisions. With a growing number of working groups, the RSPO has adopted a formal operational structure, which consists of four permanent standing committees: 1) Standards and Certification; 2) Trade and Traceability; 3) Communication and Claims; and 4) Finance. Under each of these committees, the working groups deal with long-term issues and task forces for short-term issues.

The Secretariat manages the logistical aspects of the RSPO, organises the yearly round-table meetings associated with the GA, promote the RSPO worldwide, facilitate the work of the standing committees and implement the GA decisions under BG guidance.

\section{Different strategies of NGOs}

This study finds that conservation NGOs adopt four main forms of engagement with the RSPO based on two main criteria: the resources they are allocated and the specific objectives they pursue. These categories are: collaborative, opposing, opportunistic, and sceptic. The criteria to elaborate each of those categories are detailed in Table 1.

\section{Collaborative NGOs strategies and their limitations}

Collaborative NGOs are RSPO members aiming to protect tropical forests through collaboration with the business sector. These are usually powerful international Western

Table 1

Typology of engagements of environmental NGOs with the RSPO

\begin{tabular}{|c|c|c|c|}
\hline $\begin{array}{l}\text { Form of } \\
\text { engagement }\end{array}$ & Example of conservation NGO & Resource allocated to the RSPO & Main objective pursued with the RSPO \\
\hline Collaborative & $\begin{array}{l}\text { Generalist on environment: } \\
\text { Conservation International, } \\
\text { World Resource Institute, WWF }\end{array}$ & $\begin{array}{l}\text { RSPO members } \\
\text { Actively participate into the RSPO. } \\
\text { Executive Board and different commissions } \\
\text { Engage systemically within the RSPO }\end{array}$ & $\begin{array}{l}\text { Reform the palm oil sector by influencing } \\
\text { the RSPO from within }\end{array}$ \\
\hline Opposing & $\begin{array}{l}\text { Generalist on environment: } \\
\text { Friends of the Earth, Greenpeace }\end{array}$ & $\begin{array}{l}\text { Not RSPO members } \\
\text { Elaborate files against RSPO growers } \\
\text { selected strategically } \\
\text { Use the RSPO as a tribune to protest }\end{array}$ & $\begin{array}{l}\text { Radically criticise the RSPO members, and } \\
\text { therefore RSPO in its legitimacy to reform } \\
\text { the palm oil sector from within } \\
\text { Seek to get a global moratorium on } \\
\text { deforestation and reform palm oil sector }\end{array}$ \\
\hline Opportunistic & $\begin{array}{l}\text { Organisation focussing on } \\
\text { orangutans: Borneo Orangutan } \\
\text { Survival, Hutan, PanEco and } \\
\text { Sumatran Orangutan Society }\end{array}$ & $\begin{array}{l}\text { RSPO members: } \\
\text { Exclusively participate to annual meetings } \\
\text { and general assemblies } \\
\text { Use the RSPO as a tribune }\end{array}$ & $\begin{array}{l}\text { Get specific decisions to protect particular } \\
\text { forest to save specific habitats for } \\
\text { orangutans (Tripa, Bukit Tigah Puluh, } \\
\text { degraded forest) }\end{array}$ \\
\hline Sceptic & $\begin{array}{l}\text { Generalist on environment with } \\
\text { human rights based approach: } \\
\text { most of environment and social } \\
\text { associations in the producing } \\
\text { countries, Forest Peoples } \\
\text { Programme, Sawit Watch }\end{array}$ & $\begin{array}{l}\text { Usually not RSPO members: } \\
\text { No resources allocated } \\
\text { No participation } \\
\text { If RSPO member, participate to the Board } \\
\text { of Governors and commissions, but } \\
\text { participation decreasing over time }\end{array}$ & $\begin{array}{l}\text { Seek community right recognition, question } \\
\text { the production model } \\
\text { Overtime, tend to avoid link with the RSPO } \\
\text { because of their inability to influence the } \\
\text { RSPO. RSPO tend to become secondary in } \\
\text { their strategy, distrusting this initiative that } \\
\text { diverts resources better used elsewhere }\end{array}$ \\
\hline
\end{tabular}


NGOs with headquarters in Europe (for example, WWF, Zoological Society of London, Wetlands International) or the United States (for example, Conservation International, World Resource Institute). They abide by the RSPO's overall vision to "transform markets to make sustainable palm oil the norm" (RSPO 2012: 8). This vision is similar to WWF's Market Transformation Initiative Strategy, which showcases how NGOs can influence the overall communication strategy of the RSPO (WWF 2012).

These NGOs invest a considerable amount of human and financial resources working within the RSPO system to reform the oil palm sector. The programme director of one of these international NGOs mentioned, "we have a number of people working full time on palm oil in Singapore on finance, in Indonesia and Malaysia on producers, in China and India, and across Europe and in the US on consuming business and industry engagement." 3

These resources are channelised towards four broad lines of actions to influence the RSPO system and reach conservation goals. First, they aim to create rules in the RSPO that support their conservation goals. In practice, this means putting forward RSPO GA decisions that force growers to implement the RSPO guidance document to the benefit of conservation (see below analysis of GA decisions regarding biodiversity and greenhouses gases). Even though conservation NGOs makeup less than 3\% (or 30 individual members) of all RSPO members, the RSPO GA adopted most of their decisions due to the support from a number of downstream firms. These downstream firms support the NGOs decisions not only because they reduce reputation-risks, but also because they do not bear the cost of implementing such decisions, which are supported by growers alone.

Second, they take strategic positions within the RSPO. They are a part of RSPO GB (Conservation International, then World Resource Institute, and WWF) to influence RSPO functioning. They also participate in the working groups and task forces. In those working group, they hold strategic positions as co-chairs: such as World Resource Institute for Biodiversity and Global Environmental Centre for the working group on peat. This internal lobbying by collaborative NGOs is often overlooked, as this political manoeuvring happens far from the focus of public attention. As explained by a former BG member, "WWF being inside the organisation was very critical, as I perceived them when I was a member of the board. They were not at all not criticising the companies,... but are very critical inside the organisation, pushing for criteria." 4

Third, they widely use scientific facts. As collaborative conservation NGOs are made up of scientists, they value the science-based arguments within the RSPO. As an example, the Zoological Society of London (ZSL) states that it is important "to ensure that emerging policies and good practice guidelines aiming to promote sustainable production are based on the best possible science" (Persey et al. 2011: 6). As such, they provide scientific expertise on topics such as biodiversity (i.e., ZSL), satellite mapping (e.g., World Resource Institute) and greenhouse gases (e.g., Conservation International and Wetlands International).

Fourth, they widely campaign to raise public awareness, creating external pressure in order for RSPO members to fulfil their commitments. To avoid name and shame tactics, these NGOs use collaborative techniques consisting of benchmarking different RSPO members, comparing commitments, and encouraging them to get certified (WWF 2013). As developed below, the mobilisation of these four resources has been an effective technique in challenging RSPO norms, but has also lead to some structural constraints.

\section{Limitation of collaborative approach to conserve biodiversity area}

The RSPO has developed the HCV concept to conserve areas most important to biodiversity or human well-being. Its definition and application is subject to intense discussion between growers and conservationists that have opposite opinions regarding land use. For growers, conservation areas are seen as unutilized profit space. They seek to limit the size of required conserved areas within their concessions. In contrast, NGOs consider low land areas as exceptional tropical biodiversity richness. According to this interpretation, oil palm plantation extensions must take place in already degraded areas because "there is enough non-forested land suitable for plantation development to allow large increases in production" (Fitzherbert et al. 2008: 545; Persey et al. 2011; Ruysschaert et al. 2011). Conservationists tend to maximise the designated conservation areas well beyond primary forests including degraded land (RSPO 2010).

To implement the HCV concept, in other words to define the criteria and indicators attached to it, the RSPO Biodiversity and Technical Committee (BTC) was created in 2009. However, it quickly became clear that this committee had significant scientific gaps on tropical biology. A representative from this committee summarises the situation, "sometimes, it is not clear at all. Frankly, why is biodiversity important? It is not at all obvious to demonstrate. A lot of science is needed"5. Indeed, research remains inconclusive about tropical biodiversity conservation. Results depend on the species and the level of organisation (e.g., genetic, species, or ecosystem) studied. Some studies show the importance of fragmented forest, others of the continuous forest (Benedick et al. 2006; Struebig et al. 2008; Edwards et al. 2010; Struebig et al. 2011).

As a result, this temporary committee was institutionalised as BHCV WG. This working group now aims "to provide strategic and technical support" to the RSPO (RSPO 2015f: 1 ), underlining the lasting nature of knowledge gaps. It has met 25 times between April 2009 and January 2015. Its formal structure comprises of 12 RSPO members. Two environmental NGOs hold seats in the group, one of them being co-chairs (ZSL, then World Resource Institute), and a grower holds the other seat. In addition, many other NGO members participate as observers at each meeting, accounting for more than a quarter of the participants (10 to 20). 


\section{8 / Ruysschaert and Salles}

The institutionalisation of the BTC into a permanent working group reflects the on-going and irreducible tensions between conservationists and growers. There are constant informational gaps in science and the illusion that a full scientific knowledge could arbitrate the divergent interests is sustained. As a result, on one hand collaborative NGOs seek to consolidate information to support conservation, on the other hand, growers decide which areas can be conserved on their concession in a pragmatic manner, stating that full knowledge is not yet available. Paid by the grower, evaluators tend to designate the $\mathrm{HCV}$ areas in a "subjective" and "arbitrary" manner (HCV 2007: 2), reducing the areas to conserve to the most valuable biodiversity areas. In particular, this dependency can lead the auditors to omit secondary or degraded areas because, "... the value and performance of these kinds of forest have little meaning in terms of wildlife and environment" (RSPO 2010: 16). This is the type of reasoning that Sumatran Orangutan Society (SOS) and the grower PT Sisirau opposes. As explained by a SOS's representative, "this member was clearing orangutan habitat,... but claimed it wasn't good quality forest."

\section{Limitation of collaborative approach to conserve primary forest}

With the structural knowledge gap on biodiversity impeding conservation NGOs to mobilise scientific information effectively, NGOs turned their attention to the implementation of criterion 7.3. This criterion requests preserving primary forest or HCV within the plantation after November 2005. The criterion reduces growers' room for interpretation, as it gives a clear-cut end date and which type of forest to conserve.

However, primary forest is difficult to define in practice. In addition, the 2005 date is subject to interpretation. Indeed, the criterion was agreed at RSPO GA 2007 as part of the overall agreement on the guidance document for members who seek to certify plantations. Growers consider this date relevant only when certification is foreseen. They argue that the RSPO founding members were not requested to follow these requirements in the beginning. They also add that some RSPO growers could have taken over other non-RSPO growers who may have clear-cut primary forest. As one grower explained, "We had understood that this 2005 rule applies to existing plantations, when we were starting something, we are responsible from the moment where we manage the plantation, not before." 7 To clarify these points, the RSPO GA decision endorsed WWF's proposal of 'New Planting Procedures' in 2008, jointly tabled with New Britain Palm Oil, one of the largest oil palm grower in the world ${ }^{8}$. The decision requests growers to preserve primary forest regardless if it is seeking certification or not. It entered into force in January 2010, despite growers attempt to postpone it on the grounds of practical feasibility at the GA 2009.

To take into account growers' liability, the RSPO BG set up a Compensation Task Force in 2010 as a sub-unit of the BHCV WG for an initial period of one year, with the aim to provide guidance to the BG. Four years later, in May 2014, the Task Force provided a "voluntary" guidance document (RSPO
2014: 12). This document seeks the "continuous improvement" of each grower's particular situation, refusing to expel or suspend them (RSPO 2014: 1).

In these meetings, NGOs put forward arguments based on scientific evidence. They utilised satellite technology as a method of measuring destroyed primary forest or HCV forest. However, NGOs are still unable to impose their findings for two main reasons. Science-based decisions still remain problematic. A grower at this task force meeting summarises the issue by stating, "There is still a lot of work. Coming up with a satellite imagery analysis method that can be implemented and credible is difficult." 9

Equally important, the negotiating rules (e.g., inclusive participation and consensus building) must be respected, which means that the application needs to be for all growers and adapted to each. This in turn has two implications: grower's liability should increase overtime reflecting the changing rules within the RSPO, and the mechanism needs to give enough incentive for the grower to participate. In other words, he would take actions in rehabilitating the forest and not to clear-cut this forest and pay for its destruction.

The discussions over the criterion 7.3 demonstrate irreconcilable views. For the growers, "November 2005 is absolute rubbish in the long-term and for the moment it is carved in stone"10; for the conservation NGOs, this date is indeed a non negotiable. Conservation NGOs have heavily invested in task force meetings by providing scientific evidence and participating physically. They seek to establish an adequate compensation mechanism that would definitively forbid primary forest conversion after 2005. On the opposite side, few growers have participated, blocking advance on the principles fundamental to RSPO functioning. This leads to the paradoxical situation, in which primary forest can still be cut, even if its preservation is mentioned in the RSPO guidance document.

\section{Limitations of collaborative approach to mobilise climate argument}

Having difficulty mobilising scientific arguments to preserve biodiversity and primary forest, NGOs have sought to protect biodiversity by advancing the climate change agenda. They are able to do so due to the massive release of greenhouses gases from the trees and peat when establishing oil palm plantations within tropical forests. Destruction of these forests to establish oil palm plantations releases massive amounts of greenhouse gases. The first research on greenhouse gas emissions from peat in Indonesia reveals striking figures: Indonesia is the third greenhouse gas emitter globally, behind China and the United States (Hooijer et al. 2006). An RSPO member explains that the climate agenda is a powerful argument to save peat land areas from destruction, "When you hear about the greenhouse gas emissions' study by Deltares, this is an exemplary study, in my view. This proves by A to B that we really cannot do anything on peat lands." 11

These large amounts come from two sources: the trees and the peat. Regarding the trees, the conversion of tropical 
natural forest into oil palm plantations releases carbon dioxide because tropical forest stores above ground around $190,000 \mathrm{~kg}$ of carbon per hectare, while oil palm plantations stores only around $40,000 \mathrm{~kg}$ per hectare; this means that the difference, or about $150,000 \mathrm{~kg}$ of carbon per hectare, is released as greenhouse gases when natural tropical forest is converted into an oil palm plantation. Even more important is the carbon dioxide released from the peat. This comes from the peat fires to prepare the land and the oxidation from the dry peat resulting from establishing the necessary drainage channels for the plantations (Agus et al. 2013).

At the RSPO GA 2008, Wetlands International put forward the decision 'A Moratorium On Palm Oil From Tropical Peat Lands' that requested the "cessation on any further development of palm oil on tropical peat lands" (Wetlands International 2008: 1). The RSPO BG refused this submission arguing it had been modified at the last minute after the due date for submission. It also prevented the submission of the original decision that mentioned, "The RSPO adopt that palm oil produced on peat lands be henceforth considered unsustainable until proven otherwise" (RSPO 2008: 33). Using procedural rules, RSPO BG had found ways to avoid clash between growers and conservation NGOs.

Instead of the decision, the RSPO BG put forward the core collaborative rules within the RSPO and established the Working Group Greenhouse Gas. The working group composed of the different members' categories had the aim to find a practical means to reduce greenhouses emissions by the next GA in November 2009. Facilitated by a Dutch consultant, the group was not able to conclude its work because there was no agreement on greenhouses gas emissions, and because the process was felt as a kind of neocolonialism. During the next RSPO GA in 2009, Wetlands International put forward a new proposal, the 'Establishment Of A Working Group to Provide Recommendations On How To Deal With Existing Plantations On Peat Lands'. Growers were initially against it. The representative from the Malaysian Palm Oil Association felt that, "the resolution is just to get growers to stop planting oil palm on peat after one or two cycles [which is 25 or 50 years]" (RSPO 2010: 27). Only after Wetlands International ascertained that this would not be the case, a large majority of the growers adopted the decision ${ }^{12}$.

To implement the decision, RSPO BG established Working Group 2 Greenhouse Gas, which met six times between March 2010 and May 2011. It is composed of 30 members (12 members from the Executive Board and 18 other RSPO members) and is co-chaired by an environmental NGO (Conservation International, then WWF) and one grower (MPOA, then Wilmar). On paper, this body brings together all of the RSPO membership categories. In reality, Environmental NGOs (Conservation International, Global Environmental Centre, Wetlands International, and WWF) and growers ${ }^{13}$ from Indonesia and Malaysia dominate the working group. It established the Working Group on Peat to specifically deal with the tremendous impact of peat on oil palm plantation. The working group is co-chaired by an environmental NGO (Global
Environment Centre) and a research institution (Indonesian Palm Oil Commission) linked to the Indonesian Ministry of Agriculture . It gathers six growers from Indonesia and Malaysia $^{14}$, five environmental NGOs ${ }^{15}$, four research centres ${ }^{16}$, HBSC Bank, and Neste Oil, a Finnish agro-fuel company.

Working Group 1 and 2 Greenhouse Gas and the Working Group Peat have been subject to intense debate between conservation NGOs and growers. This reflects their fierce opposition to each other's conservation goals. Conservation NGOs advanced scientific published researches on greenhouse gases. Growers challenge them on the ground that they are generalities far from describing the specific reality at plantation level. Indeed, at local level, greenhouse gas emissions depend on at three parameters: 1) drainage canal depth;2) number of years of operation; and 3) fertiliser dosage. As one scientist summarised: "We find a relationship with the depth of the canal and the carbon emission, but it changes overtime. In the first few years you have high emissions, and with time it settles on different relationships. In the long term, it settles with low emission with a peat depth of $40 \mathrm{~cm}$ or lower."17 To fill this scientific knowledge gap on greenhouse gases emissions linked to oil palm, NGOs, especially Conservation International, have undertaken some researches from the RSPO. In 2013, the RSPO published its findings. But, they are not authoritative as some results are contradictory, due to the varying methodologies used (Killeen and Goon 2013). Therefore, the conservation NGO leading the publication has put out a call for more research instead of advocating for immediate action (Killeen and Goon 2013).

Additionally, growers argued that management principles at the core of RSPO functioning must be respected. Each grower must establish its greenhouses gas reductions on a voluntary basis to ensure long-term economic viability of the plantation. Indeed, each grower faces specific circumstances: the state of development of its 25-years plantation; the prospect to extend onto new peat land areas; the relative area of plantation on peat compared to the total oil palm plantation area; and the plan of its conservation efforts.

After four years of negotiations, the RSPO agreed in a new guidance document that takes into account specific focus on greenhouse gases during their April 2013 GA. The document mentions "to reduce" (RSPO 2013: 32, criterion 5.6) and "to minimise" (RSPO 2013: 56, criterion 7.8) greenhouses gases emissions. Collaborative NGOs that were heavily involved in this process expressed their satisfaction with the results of these negotiations as they were able "to strengthen wording on GHG and peat lands and avoiding high carbon stock land" 18 . However, reality is that without tangible objectives and a clear deadline, producers can postpone any effort in the name of feasibility. As a consequence, to implement these new greenhouse gas criteria, RSPO established yet another working group: The Emission Reduction Working Group.

\section{Opponent NGOs'strategies and their limitations}

Opponent NGOs seek to protect tropical forest though a no deforestation commitment. These are powerful Western NGOs, 
among them, Greenpeace and Friends of the Earth. They do not consider the RSPO as a credible means to produce sustainably. As an example, Greenpeace report Certifying Destruction explains why companies need to go beyond RSPO commitment (Greenpeace 2013). Opponent NGOs use the RSPO as a platform to expose bad practices in the supply chain. They are not RSPO members to avoid legitimising the organisation.

Opponent NGOs mobilise considerable resources to influence the RSPO to their advantage. First, they can mobilise (scientific) expertise, by investigating and establishing evidence against prominent growers who breach RSPO rules (for example, Wilmar, Golden-Agri Resources). Second, with their close relationship to the media and the public, they are able to undertake aggressive campaigning targeting key RSPO members using a wide range of media tools, for example, the video Nestlé Killer or fact-sheets How Unilever Suppliers are Burning up Borneo.

As they are not RSPO members, opponents cannot create RSPO rules or take strategic positions within the RSPO. For that, opponent NGOs benefit from the work of collaborative NGOs that are able to put forward decisions and hold strategic positions within the RSPO.

The strategic collaboration between the opponent and the collaborative NGOs began when Greenpeace made a public case against the Malaysian grower United Plantation, who had breached the rules to implement the RSPO guidance document (Greenpeace 2008). In response to the case, WWF put forward a resolution on new planting procedures at the GA 2008. The decision forces growers to engage in public consultation for all new plantation permits, which are the state authorisations to plant oil palm on long-term governmental lease. Growers must publish on the RSPO website the key information on their plantations' plan for the duration of 30 days: this includes a map with the coordinates; a summary of the environmental impact assessment; and a summary of the development plan. With this resolution, opponent NGOs have had access to far more information on the RSPO growers. Accordingly, they were able to file many more cases against RSPO growers. As of April 2015, 50 cases had been brought to the RSPO (RSPO $2015 \mathrm{c}$ ). The rising number of cases were new opportunities for the collaborative NGOs, especially Oxfam/Novib and Sawit Watch. They could influence the RSPO in order to set up a formal grievance system open to members and non-members.

At the first glance, collaborative and opponent NGO strategies generated a virtuous circle that strengthened the grievance system, facilitating the work of the opponent NGOs to identify new cases. However, the system puts burden on opponent NGOs as they must sustain their claim through the slow procedure, often lasting for about two years for each case, due to the participatory and consensual approach within the RSPO. In addition, these NGOs can only focus on some specific cases, pooling their resources where it will have the greatest political impact. Indeed, growers are powerful actors with wide technical, financial, and political resources. Growers can turn low-income local communities against NGOs by compensating them for the land loss. They also can use comprehensive marketing strategy with a dedicated communications department (Wilmar 2011; GAR 2011). This can discredit NGO-led international campaign. As a result of these constrains, opponent NGOs acknowledge that, "We are targeting the big one to make that big move. You know that we have been campaigning on XXX ... and it's because they are the biggest one, and then the biggest threat."19

\section{Opportunistic NGOs strategies and their limitations}

The opportunistic NGOs are the RSPO members that seek to protect specific species and their habitat. Operating in Indonesia and Malaysia, they mainly focus on the Sumatran Orangutan (PanEco and Sumatran Orangutan Society) and the Borneo Orangutan (for example, Borneo Orangutan Society, Hutan, and Orangutan Land Trust). Their financial and human resources are rather limited, but they benefit from a long-term scientific expertise with deep knowledge in the field.

Initially, the opportunistic NGOs are rather unpredictable in the RSPO, as they adopted opponent or collaborative strategies depending on the situation. Behaving as collaborative NGOs, they put forward decisions during the RSPO GA to preserve specific territories: cultivate palm oil on degraded land (by PanEco in 2006), conserve Tripa peat swamp forest (PanEco in 2008), conserve Bukit Tigah Puluh ecosystem (SOS in 2009), and conserve non-primary forest (SOS in 2010). In the GAs, opportunistic NGOs can be very hard on the RSPO system. PanEco's resolution on Tripa mentioned, "we request the RSPO to adhere to the credibility of its role and drastically improve its efficiency by implementing an effective mechanism to control bad practices of the palm oil industry" (RSPO 2008: 39). Exceptionally, opportunistic NGOs have also put forward GA decisions of much boarder scope as the SOS decision 'Transparency in Plantations Concession Boundaries' adopted in 2013. This decision requests grower to provide the coordinates of each of its concession, allowing NGOs to monitor what is happening on the ground in real time through remote sensing. They also actively participate on the different bodies that the RSPO have established to deal with biodiversity related decisions, such as the BHCV WG and Compensation Task Force. However, unlike the collaborative NGOs, they do not take strategic positions as co-chairs, but provide more scientific research-based evidences as participants. Behaving as opponent NGOs, so-called opportunistic NGOs also file complaint cases against RSPO members, produce fact-findings evidence, and seek media exposure.

Changing their role to get the most impact, opportunistic NGOs are unpredictable within the RSPO. By institutionalising, the RSPO dramatically reduced the possibility for opportunistic NGOs to change roles. Growers successfully put forward the decision 'Preserving the Integrity of the Standard Setting Process in RSPO' at the 2010 GA. This decision forbids opportunistic NGOs to put forward decisions that support their particular agenda. In addition, the RSPO created the codes of conduct, one for all their members and the other for the BHCV WG members that limit opportunistic strategies (RSPO 2015 d,e). The BHCV WG code of conduct requests 
that the member's "participation reinforces positive public image of the RSPO" (RSPO 2015e: 1), and details a section about confidentiality for members in the working group. In other words, the code of conduct prevents opportunistic NGOs to adopt an opponent strategy or to collaborate with opponent NGOs, if the discussions as collaborative NGOs within the BHCV WG do not turn to their advantage.

As a result of RSPOs' institutionalisation, opportunistic NGOs have to choose between a collaborative and an opponent strategy, both limiting their impact on the RSPO. Involved with the RSPO for over 10 years, most of these NGOs tend to adopt a collaborative strategy, sometimes reluctantly. For example, SOS continued its membership despite announcing their departure from the RSPO in November 2014.

\section{Sceptic NGOs strategies and their limitations}

Sceptic NGOs seek recognition of the communities right to land and therefore conserve biodiversity and forest. Indeed, local communities have sustainably managed those biodiversity rich forest areas that are now threatened by oil palm plantations (Putri 2010). These sceptics are mostly operating in the producing countries with long-term social and environmental agendas (for example, the World Conservation Society, the Leuser International Foundation, Sawit Watch, Whali, Forest Peoples Programme). Most of them are not RSPO members, expect for Forest Peoples Programme and Sawit Watch, which is a network of 40 social and environmental Indonesian NGOs. (Jiwan 2013).

As the main sceptic NGO RSPO member, Sawit Watch used three main avenues in the RSPO to reach its goals. Firstly, it put forward GA decisions such as 'The need for a task force on smallholders' at the GA2, co-signing them with international NGOs, producers, and downstream firms. Secondly, it held the strategic position of representative of the social NGOs at the Executive Board to influence the implementation of these decisions. Thirdly, it maintained strategic relationships at the grass-root level facilitating the participation of the locals in the RSPO. Local participation took three forms: 1) they brought violation cases of the RSPO standard against growers to the complaint panel; 2) they expressed their views at the RSPO annual meeting; and 3) they organised mass protests during the annual RSPO meetings for weak RSPO standards for social issues (Parker 2013).

Despite the anecdotal achievements of getting the minority voice heard during the round table meetings, this strategy did not achieve its goals. The prevalent management discourse within the RSPO process discredited this land right-based argumentation (Cheyns 2014). The RSPO's institutionalisation strengthened this structural problem overtime by widening the discursive gap. By adopting this discourse, collaborative and opponent NGOs also marginalised the sceptic NGOs and their conservation agenda within the RSPO system.

It is, therefore, not a surprise that Sawit Watch gradually lost interest in the RSPO scheme. As a main consequence, it left the RSPO BG in 2012. Only Forest Peoples Programme has stood firmly active, focussing on the Free, Prior and Informed
Concerned (FPIC) indicator of the guidance document (Cholchester and Chao 2014). If applied, the sceptic NGOs believe that the FPIC could be a powerful tool to get locals their rights to land recognised on oil palm areas.

In conclusion, sceptics tend to avoid links with the RSPO due to their inability to influence the RSPO to truly include land-right issues. The RSPO tends to become secondary in their overall strategy. The sceptics distrust this initiative that diverts their limited resources. Working closely in the field, sceptics do not believe the RSPO can deal with the underlining sociopolitical-economic roots of forest destruction, such as the lack of local land right recognition, the high short-term economic return, the lack of law enforcement and the promotion of large-scale agricultural model. They remain highly sceptical in regards to the sudden conversion to the sustainability agenda by all of these big producers. A representative of one of the NGOs summarises the general feeling: "I have told you since the beginning. It's a waste of time [the RSPO]. It's pure brain washing. I haven't seen any of these oil palm people taken to court." 20

\section{CONCLUSIONS AND PERSPECTIVES}

This research demonstrated the importance of taking a political ecology approach and considering the diversity of NGOs' engagement with the RSPO. As strategic players with clear goals are mobilising their limited resources, conservation NGOs use four broad differing strategies (or roles) to make conservation gains: 1) Collaborative approaches seek to change the system from within by providing scientific research-based information, holding strategic positions and creating rules; 2) Opponent NGOs remain outside the RSPO while using it as a platform for public campaigns; 3) Opportunistic strategies focus on conserving geographical areas, adopting either collaborative or opponent strategies to reach their goals; and 4) Finally, those adopting the role of the 'Sceptic' take a rights-based approach to conservation by working with local communities to stop oil palm plantation expansion.

Within these strategies, conservation NGOs play a vital role in strengthening biodiversity conservation within the RSPO. This includes the adoption of many GA decisions, the creation of a comprehensive complaints system, BHCV WG, a Compensation Task Force and a Working Group on Greenhouse Gases. All of these rules and institutions help to strengthen the RSPO standard and the provisions for its implementation.

However, the RSPO system has largely failed to support NGOs in reaching their initial conservation goals. The going mobilisation of NGO resources and response from other players, especially growers and downstream actors (processors, manufacturers, retailers), has co-constructed and institutionalised the RSPO in such a way that it constrains the NGOs. This limits NGOs' options, preventing them from reaching their initial goals. As such, NGOs have only obtained some very minor conservation outcomes. Three additional reasons for this were found. The initial reason is that 


\section{2 / Ruysschaert and Salles}

institutionalisation forces each individual NGO to keep to a specific strategy while their resources are decreasing whereas RSPO is structuring. Then, the institutionalisation impedes collaboration between NGOs using different strategies, while this collaboration is key to get leverage. Lastly, sceptic NGOs are structurally excluded because of their incompatibility with the prevalent capitalistic discourse within the RSPO, while their participation is fundamental both in term of long-term conservation gains and social justice.

Conservation NGOs are directly responsible for this situation. Indeed, the RSPO system tends to promote a collaborative strategy that uses scientific research-based managerial discourses with a focus on technologies such as remote sensing. Collaborative NGOs fully engage providing scientifically based information on biodiversity loss, deforestation or climate change. However, those NGOs are never able to provide all of the needed information. There are always some measurement uncertainties at the local level. In addition, the cardinal consensus-building rule itself promotes the market logic (Büsher 2008). Indeed, each agreement in a working group is incomplete with on-going adjustments of the means and goals (McCarthy 2012). As such, the working groups that conservation NGOs have succeeded in establishing evolve into long-term institutions. They digest NGO criticism through a science-based management process (Boltanski and Chiapello 1999). As a result, the RSPO still allows biodiversity loss, deforestation, and greenhouse gas emissions. Having contributed to reinforcing the RSPO system for more than 10 years, collaborative NGOs seem to have no other option but to unconditionally promote the RSPO. For instance, in 2013, an NGO advocated in favour of the RSPO guidance document endorsed at the GA 2013 despite its flaws: "On balance the new P\&Cs [Principles \& Criteria] are not the end point but a step on the way to transforming the industry and as such, I think we should support the revisions [of the guidance document] and encourage others to do so." 21

Opponent NGOs initially cooperate with collaborative NGOs to expose bad practices of RSPO members and to reinforce the RSPO complaints system. However, opponent NGOs can only focus on specific cases against the largest RSPO growers by pooling their limited resources where it will have the greatest political impact. As a result, opponent NGOs can only play the role of external supervisor, a role normally given to the state, without having the financial and coercive power of the state. Opportunistic NGOs initially use collaborative or opponent strategies within the RSPO to protect specific geographical areas. However, with RSPO's institutionalisation, they are forced to choose between the two strategies as new RSPO rules force all RSPO members to promote RSPO. Reluctantly, they tend to select the collaborative strategy. Finally, NGOs adopting the role of the sceptic seek recognition of local land rights but their requests are marginalised and not taken into consideration within the RSPO system. They tend to leave the RSPO, even though land rights and more broadly local issues are a fundamental matter of concern for biodiversity conservation. NGOs are also unable to get leverage on the
RSPO from developing collaborative strategies between different NGO categories. This is due to the fact that the RSPO has adopted two formal codes of conduct, one for its members and one for the BHCV WG, which force all RSPO members to adopt only collaborative strategies.

In summary, by analysing NGO strategies relative to the RSPO and main actor agendas, and how NGOs participate or oppose based on their own motivations, this research deepens our understanding of why conservation NGOs obtain poor conservation outcomes. In the case of the RSPO, it results from the growing gap between the intent (the initial goal of NGOs) and the allowed actions in an always more constrained environment. What appear as 'alliances' (Igoe et al. 2010a: 486) between growing markets and conservation may be experienced by the NGOs as their only possible choice, or at least the most feasible one.

Yet, what can the NGOs do to get better conservation outcomes? One option would be for NGOs to clearly focus on their initial conservation objective by mobilising additional resources in an always more constrained system, another option would be to collaborate on a collective conservation or human rights objective with other NGOs using different strategies in order to get some leverage (Ruysschaert 2013). At the field level, sceptic NGOs could support local communities to regain recognition of their land rights. Along the supply chain, collaborative NGOs could focus on transparency and traceability. The World Resource Institute with its Global Forest Watch and ZSL with its Sustainable Palm Oil Platform (ZSL 2015) are already actively participating in this. At the consumer level, opponent NGOs would be able to expose bad practices of main players (e.g., producers, traders, financial institutions) by using information that has been made available by collaborative NGOs. Finally, opportunistic NGOs would benefit from the work of the other NGOs and apply it on specific territories.

To test if the NGOs would benefit more from focussing on their specific objective or from collaborative strategies to get an impact, one should conduct a more detailed institutional ethnographic of a selection of NGOs, which is beyond the scope of this study. An ethnographic analysis of the NGOs involved in the Palm Oil Innovative Group (POIG) may be a promising avenue (POIG 2013). The POIG brings together several proactive RSPO growers and NGOs from the four engagement strategies: 1) WWF (collaborative), 2) Greenpeace (opponent), 3) Forest Peoples Programmes (sceptics), and 4) SOS (opportunistic). POIG members commit to respecting both human rights and 'no deforestation', which includes the preservation of all peat lands and forest above a certain carbon stock threshold.

\section{ACKNOWLEDGEMENTS}

This paper draws heavily on Denis Ruysschaert's Ph.D. on the role of conservation NGOs in biodiversity loss (Ruysschaert 2013). Thank you for the comments from the three anonymous reviewers and the editor. Thank you to Vi Tran, Stephen Caudwell and Mira 
Gratier for their English editing. Thank you to Satu Ojaluoma for her moral support.

\section{NOTES}

1. Aquaculture Stewardship Council, Better Cotton Initiative - BCI, Roundtable on Sustainable Biofuels - RSB, Better Sugar Cane Initiative - Bonsucro, Roundtable on Responsible Soy - RTRS.

2. 1) Commitment to transparency;2) compliance with applicable laws and regulations; 3 ) commitment to long-term economic and financial viability; 4) use of appropriate best practices by growers and millers; 5) environmental responsibility and conservation of natural resources and biodiversity; 6) responsible consideration of employees and of individuals and communities affected by growers and mills; 7) responsible development of new plantings; and 8) commitment to continuous improvement in key areas of activity.

3. Environmental NGO Interview April 20, 2012.

4. Retailer funding member RSPO December 10, 2012.

5. Interview November 28, 2011.

6. SOS interview March 18, 2012.

7. Grower interview February 13, 2012.

8. Sime Darby, the largest oil palm grower in the world, bought New Britain Oil Palm in March 2016.

9. Grower interview February 13, 2012.

10. Grower interview February 13, 2012.

11. Interview November 18, 2011.

12. 95 for, 4 against, 22 abstentions.

13. Three growers from Indonesia (PT Smart, Musim Mas, Gapki) and three from Malaysia (IOI, Kulim Bernhard, Sime Darby, Wilmar).

14. Indonesian growers (PT Indonesia Plantations, Asian Agri Group, GAPKI, PT Smart) and Malaysian growers (United plantations, Sime Darby).

15. Conservation International, Wetlands International, WWF International, WWF Malaysia, and WWF Indonesia.

16. Palanka Raya Indonesia University, Parum Agricultural Soil Survey, Delft Hydraulics, Leicester University.

17. Research Institute Interview November 10, 2011.

18. Interview November 28, 2011.

19. Interview November 23, 2011.

20. Interview November 19, 2011.

21. E-mail to all NGOs regarding RSPO vote on the new P\&C. April 9, 2013.

\section{REFERENCES}

Agus, F., I.E. Henson, B.H. Sahardjo, N. Harris, M. van Noordwijk, and T.J. Killeen. 2013. Review of emission factors for assessment of CO2 emission from land use change to oil palm in Southeast Asia. In: Reports from the Technical Panels of the Second RSPO GHG Working Group (eds. Killeen, T.J., and J. Goon). Pp. 7-31. Kuala Lumpur: RSPO.

Barker, M. 2009. When Environmentalists Legitimize Plunder. Swans Commentary 15, http://www.swans.com/library/art15/barker12.html. Accessed on October 05, 2015.

Benedick, S., J. Hill, N. Mustaffa, V. Chey, M. Maryati, J. Searle, M.
Schilthuizen, and K. Hamer. 2006. Impacts of rainforest fragmentation on butterflies in northern Borneo: species richness, turnover and the value of small fragments. Journal of Applied Ecology 43(5): 967-977.

Benjaminsen, T. and H. Svarstad. 2010. Questioning conservation practice and its response: the establishment of Namaqua National Park. Current conservation 3(3): 8-13.

Boltanski, L. and E. Chiapello. 1999. Le nouvel esprit du capitalisme. Paris: Gallimard.

Brockington, D. 2011. A brief guide to (conservation) NGOs. Current Conservation 5(1): 30-31.

Brockington, D. and R. Duffy 2010. Capitalism and conservation. The production and reproduction of biodiversity conservation. Antipode 42(3): 469-484.

Büscher, B. 2008. Conservation, neoliberalism, and social science: a critical reflection on the SCB 2007. Annual Meeting in South Africa. Conservation Biology 22(2): 229-231.

Büscher, B., W. Dressler, and R. Fletcher (eds.). 2014. Nature Inc.: environmental conservation in the neoliberal age. Tucson, AZ: University of Arizona Press.

Chaplin, M. 2004. A challenge to conservationists. World Watch Magazine 17(6): 17-31.

Cheyns, E. 2012. (Dé) politisation des standards dans les dispositifs de normalisation multiparties prenantes. Les cas du soja et de l'huile de palme. In: Normaliser au nom du développement durable (eds. Alphandréry, P., M. Djama, and A. Fortier). Pp.101-118. Versailles: Quae.

Cheyns, E. 2014. Making "minority voices" head in transnational round tables: the role of NGOs in reintroducing justice and attachments. Agriculture and Human Values 31(3): 439-453.

Cholchester, M. and S. Chao. 2014. Revising the RSPO guide on free, prior and informed consent. Conclusions and questions. RT12. Moreton-inMarsh: Forest Peoples Programme.

Colchester, M. and S. Chao (eds). 2011. Oil Palm Expansion in South East Asia. Trends and implications for local communities and indigenous peoples. Moreton-in-Marsh: Forest Peoples Programme and Sawit Watch.

Corzier, M. and E. Frieberg. 1977. L'acteur et le système. Paris: Seuil.

DGEC. 2014. 2013-2015 Tree crop estate statistics of Indonesia. Palm Oil. Jakarta: Directorate General of Estate Crops.

Edwards, D., J. Hodgson, K. Hamer, S. Mitchell, A. Ahmad, S. Cornell, and D. Wilcove. 2010. Wildlife-friendly oil palm plantations fail to protect biodiversity effectively. Conservation Letters 3(4): 236-242.

Escobar, M. and E. Cheyns. 2012. NGOs acting along global supply chains: between market and politics. An assessment of campaign and regulatory devices in the palm oil and soy sectors. In: Workshop: responsible supply chains and networks: challenges for governance and sustainability. November 22-24, 2012. Stockholm: Södertörn University.

Fitzherbert, E., M. Struebig, A. Morel, F. Danielsen, A. Brühl, P. Donald, and B. Phalan. 2008. How will oil palm expansion affect biodiversity? Trends Ecology and Evolution 23(10): 538-545.

Fouilleux, E. 2013. Normes transnationales de développement durable. Gouvernement \& action publique 2(1): 93-119.

Fouilleux, E. and F. Goulet. 2012. Firmes et développement durable: le nouvel esprit du productivisme. Etudes rurales 190: 131-146.

Friedberg, E. 1991. Le pouvoir et la règle. Dynamiques de l'action organisée. Paris: Seuil.

GAR. 2011. Forest conservation policy. Kuala Lumpur: Golden Agri Resource.

Gautier, D. and T. Benjaminsen. 2012. Introduction à la political ecology. In: Environnement, discours et pouvoir. L'approche Political Ecology. (eds. Gautier, D. and T. Benjaminsen). Pp. 5-20. Versailles: Quae.

Greenpeace. 2008. United Plantations certified despite gross violations of RSPO standards. Amsterdam: Greenpeace International. http:// www.greenpeace.org/international/Global/international/planet-2/ 
report/2008/11/united-plantations-certified-d.pdf. Accessed on March $10,2015$.

Greenpeace. 2013. Certifying destruction. Why consumer companies need to go beyond the RSPO to stop forest destruction. Amsterdam: Greenpeace International. http://www.greenpeace.de/files/publications/rspocertifying-destruction.pdf. Accessed on March 10, 2015.

HCV. 2007. Expert Workshop on Methods for Landscape HCV. February 12-13, 2007. Bogor: WWF.

Hooijer, A., M. Silvius, H. Wösten, and S. Page. 2006. PEAT-CO2: assessment of $\mathrm{CO} 2$ emissions from drained peatlands in SE Asia. Delft, the Netherlands: Delft Hydraulics. http://www.stockandland.com.au/news/ agriculture/agribusiness/general-news/adm-ups-wilmar-stake/2719170. aspx 09. Accessed on April 29, 2015.

Igoe, J. 2005. Global indigenism and spaceship earth: convergence, space, and reentry friction. Globalizations 3(2): 377-390.

Igoe, J. and D. Brockington. 2007. Neoliberal conservation: a brief introduction. Conservation and Society 5(4): 432-449.

Igoe, J., K. Neves, and D. Brockington. 2010a. A spectacular eco-tour around the historic bloc: theorising the convergence of biodiversity conservation and capitalist expansion. Antipode 42(3): 486-512.

Igoe, J., S. Sullivan, and D. Brockington 2010b. Problematising neoliberal biodiversity conservation: displaced and disobedient knowledge. Current conservation 3(3): 4-7.

IUCN. 2015. IUCN Red List of threatened species. www.iucnredlist.org. Accessed on June 25, 2015.

Jiwan, N. 2013. The political ecology of the Indonesia palm oil industry, a critical analysis. Pp. 48-75. In: The palm oil controversy in South East Asia. A transnational perspective. (eds. Pye, O. and J. Bhattacharya). Pp. 48-75. Singapore: Institute of Southeast Asian Studies.

Killeen, T.J. and J. Goon (eds.). 2013. Reports from the technical panels of the second RSPO GHG working group. Kuala Lumpur: RSPO.

Margono, B., P. Potapov, S. Turubanova, F. Stolle, and M. Hansen. 2014. Primary forest cover loss in Indonesia over 2000-2012. Nature Climate Change 4: 730-735.

McCarthy, J. 2002. First World political ecology: lessons from the wise use movement. Environment and Planning A 34(7): 1281-1302.

McCarthy, J. 2012. Certifying in contested spaces: private regulation in Indonesian forestry and palm oil. Third World Quarterly 33(10): 1871-1888.

Miettinen, J., A. Hooijer, S. Chenghua, D. Tollenaar, R. Vernimmen, S. Chin Liew, C. Mallins, and S. Page. 2012. Extent of industrial plantations on Southeast Asian peatlands in 2010 with analysis of historical expansion and future projections. GCB Bioenergy doi: 10.1111/j.17571707.2012.01172.x

Oosterveer, P. 2014. Promoting sustainable palm oil: viewed from a global networks and flows perspective. Journal of Cleaner Production 107: 1-8.

Parker, D. 2013. Palm oil workers stage massive protest at sustainability meeting in Indonesia. November 19. Mongabay. http://news.mongabay. com/2013/1119-dparker-palm-oil-worker-protest.html. Accessed on June 13, 2014.

Peluso, N. 2012. Situer les political écologies: l'exemple du caoutchouc. In: Environnement, discours et pouvoir. L'approche Political Ecology. (eds. Gautier, D. and T. Benjaminsen). Pp. 37-65. Versailles: Quae.

Persey, S., R. Nussbaum, M. Hatchwell, S. Christie, and H. Crowley. 2011. Towards sustainable palm oil: a framework for action. Cambridge: ZSL/Proforest/WCS.

POIG, 2013. Palm oil innovations group charter. http://www.greenpeace.org/ international/Global/international/photos/forests/2013/Indonesia $\% 20$ Forests/POIG\%20Charter\%2013\%20November\%202013.pdf. Accessed on June 14, 2015.

Ponte, S., J. Vestergaad, and P. Gibbon (eds). 2011. Governing through standards: origins, drivers and limits. London: Palgraves.

Putri, N. 2010. Building a state, dispossessing the nation: sovereignty and land dispossession in Indonesia. Ph.D. thesis. Graduate Institute, Geneva, Switzerland.

Pye, O. 2013. The political ecology of the Indonesia palm oil industry, a critical analysis. In: The palm oil controversy in South East Asia. A transnational perspective. (eds. Pye, O. and J. Bhattacharya.) Pp. 179-198. Singapore: ISEAS Publishing.

Pye, O. and J. Bhattacharya. 2013. The palm oil controversy in Southeast Asia. A transnational perspective. Singapore: ISEAS Publishing.

RSPO 2002. Minutes of the preparatory meeting, September 20. London: RSPO.

RSPO 2011. Vision and mission. Kuala Lumpur: RSPO. http://www.rspo.org/ about. Accessed on April 29, 2015.

RSPO. 2004. Statutes - roundtable on sustainable palm oil. Kuala Lumpur: RSPO.

RSPO. 2007. RSPO Certification Systems. Final document approved by RSPO Executive Board. 26 June 2007. Kuala Lumpur: RSPO. http://www. rspo.org/sites/default/files/RSPOcertification-systems.pdf. Accessed on March 20, 2014.

RSPO. 2008. Minutes of the $5^{\text {th }}$ general assembly of the roundtable on sustainable palm oil. Kuala Lumpur: RSPO. http://www.rspo.org/files/ resource_centre/MinutesGA5.pdf. Accessed on March 20, 2014.

RSPO. 2010. Roundtable on sustainable palm oil $7^{\text {th }}$ general assembly. Kuala Lumpur: RSPO. http://www.rspo.org/file/GA7\%20Minutes.pdf. Accessed on March 20, 2014.

RSPO. 2012. Roundtable on sustainable palm oil $8^{\text {th }}$ general assembly. Kuala Lumpur: RSPO. http://www.rspo.org/resources/supplementarymaterials/minutes-reports-of-rspo-ga-ega. Accessed on June 21, 2016.

RSPO. 2013. Principles and criteria for the production of sustainable palm oil. Kuala Lumpur: RSPO. www.rspo.org/publications/ download/224fa0187afb4b7. Accessed on June 21, 2016.

RSPO. 2014. Task force compensation recommendations. Kuala Lumpur: RSPO. http://www.rspo.org/file/2 RSPORemediationandCompensationProcedures_May2014.pdf. Accessed on June 21, 2016.

RSPO. 2015a. Members. Kuala Lumpur: RSPO. http://www.rspo.org/ members/all. Accessed on May 20, 2015.

RSPO. 2015b. Impact. Latest update on 17 June 2015. http://www.rspo.org/ about/impacts. Accessed on July 05, 2015.

RSPO. 2015c. Complaints. Kuala Lumpur: RSPO. http://www.rspo.org/ members/complaints. Accessed on April 29, 2015.

RSPO. 2015d. Code of conduct for members of the RSPO. Kuala Lumpur: RSPO. http://www.rspo.org/files/resource_centre/CoC.pdf. Accessed on June 21, 2016.

RSPO. 2015e. Code of conduct policy statement - RSPO BHCV working group. Kuala Lumpur: RSPO. http://www.rspo.org/about/who-we-are/ working-groups/biodiversity-high-conservation-values. Accessed on June 21, 2016.

RSPO. 2015f. Biodiversity and high conservation value working group. Kuala Lumpur: RSPO. http://www.rspo.org/about/who-we-are/ working-groups/biodiversity-high-conservation-values. Accessed on May 10, 2015.

Ruysschaert, D. 2013. Le rôle des organisations de conservation dans la construction et la mise en oeuvre de l'agenda international de conservation d'espèces emblématiques: le cas des orangs-outans de Sumatra. Ph.D. thesis. University Jean Jaurès, Toulouse, France.

Ruysschaert, D. and D. Salles. 2014. Towards global voluntary standards: Questioning the effectiveness in attaining conservation goals. The case of the roundtable on sustainable palm oil (RSPO). Ecological Economics 107: 438-446.

Ruysschaert, D., A. Darsoyo, R. Zen, G. Gea, and I. Singleton. 2011. Developing palm-oil production on degraded land. Medan: PanEco, YEL and World Agroforestry Centre.

Sachedina, H., J. Igoe, and D. Brockington. 2010. The spectacular growth 
of a conservation NGO and the paradoxes of neoliberal conservation. Current conservation 3(3): 24-27.

Struebig, M., T. Kingston, A. Zubaid, A. Mohd-Adnan, and S. Rossiter. 2008 Conservation value of forest fragments to Palaeotropical bats. Biological Conservation 141(8): 2112-2126.

Struebig, M., T. Kingston, E. Petit, S. Le Comber, A. Zubaid, A. Mohd-Adnan, and S. Rossiter. 2011. Parallel declines in species and genetic diversity in tropical forest fragments. Ecology Letters 14(6): 582-590.

Tumusiime, D. and H. Svarstad. 2011. A local counter-narrative on the conservation of mountain gorillas. Forum for Development Studies 38(3): 239-265.

USDA. 2014. United States Department of Agriculture PSD database. Agricultural production, supply, and distribution. Washington, DC: USDA. http://www.indexmundi.com/agriculture/. Accessed on June 25, 2014.

Wetlands International. Amended Resolution 19 November 2008. $5^{\text {th }}$ RSPO General Assembly. Wageningen, the Netherlands: Wetlands International.

Wich, S.A., Riswan, J. Jenson, J. Refisch, and C. Nellemann (eds). 2011.
Orangutans and the economics of sustainable forest management in Sumatra. Trykkeri: GRASP/ YEL/ ICRAF/ GRID-Arendal.

Wilmar. 2011. Sustainability report 2011: staying the course through challenging times. Singapore: Wilmar international.

WWF 2012. Market transformation initiative strategy. Gland: WWF International http://awsassets.panda.org/downloads/market transformation_initiative_strategy_1.pdf. Accessed on April 29, 2015.

WWF, ZSL and GFN. 2014. WWF living planet report 2014. Species and paces, people and places. Gland: WWF, Zoological Society of London and Global Footprint Network. http://wwf.panda.org/about_our_earth/ all_publications/living_planet_report/. Accessed on July 05, $20 \overline{1} 5$.

WWF. 2013. WWF assessment of RSPO member palm oil producers 2013. Gland: WWF International. http://wwf.panda.org/what_we_do/ footprint/agriculture/palm_oil/solutions/responsible_purchasing/ wwf_assessment_of_rspo_member_palm_oil_producers_2013/. Accessed on April 29, 2015.

ZSL. 2015. Sustainable Palm Oil Platform. Cambridge: Zoological Society of London. http://www.sustainablepalmoil.org/. Accessed on April 29, 2015. 